\title{
Hints of age bias spur calls for grant reforms
}

David Cyranoski and Keiko Kandachi, Tokyo

The older you are, the more funding you get, according to figures released earlier this year by Japan's highest science and technology body, the Council for Science and Technology Policy (CSTP).

Now the CSTP has set up a committee to debate what measures, if any, should be taken to redress the balance and increase financial autonomy for young researchers. It is scheduled to report back in March.

The figures were compiled from all seven of Japan's grant-giving agencies for the fiscal year 2001; the first time such a complete survey has been done. They reveal a marked imbalance, showing that $71 \%$ of the money goes to researchers aged 45 or over, with those over 50 getting more than half of all grant funding.

The issue isn't confined to Japan: figures released last year by the US National Institutes of Health $(\mathrm{NIH})$ revealed that principal investigators aged 40 and under got only $16 \%$ of the 6,961 competitive research grants that it awarded in 2001.

For some, this pattern is out of sync with the age at which researchers are most productive. "We need to shift more funds to those younger people," says Masahiko Aoki, an economist at Stanford University and a special adviser to the CSTP's review committee. He points to data on the CSTP's website

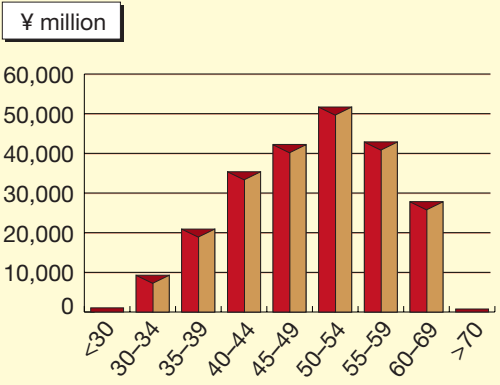

Uneven: grant funding in Japan by age for 2001.

that suggest that most Nobel laureates do their prizewinning research in their thirties.

But Japan's bureaucrats are not convinced. An official at the education ministry says that thanks to programmes set up five years ago, $28 \%$ of the ministry's grants for 2001 went to researchers under 40 . Even officials at the health ministry, where only $2.4 \%$ of last year's 1,400 grants went to researchers under 36 , were unconcerned. The ministry's grants are "mission-oriented" and not intended "to give young people funds to be creative with", says one official.

Hiroo Imura, chairman of the CSTP committee and the former president of Kyoto University, sees the real issue as whether a small, established group of older scientists gets too much funding. "We think it's important to avoid giving several government grants to a handful of researchers," he says.

Immunologist Kimishige Ishizaka, who is another adviser on the CSTP committee and was formerly at the La Jolla Institute for Allergy and Immunology in California, blames both universities and funding agencies for this effect. Neither steps in to ensure that researchers are not overextending themselves or duplicating research, he says.

But like Aoki, Ishizaka thinks that the real problem is that young researchers cannot be independent, and he blames Japan's brief application forms, which usually describe a research plan in just two pages. "You can't tell what's unique or how the proposed project compares to others," he says. "It's impossible to evaluate on this basis." So decisions are based mainly on past records, which favours older researchers, Ishizaka explains.

Although figures show that Japanese under 40 are relatively successful at getting grants $(27 \%$ compared with the NIH's $16.3 \%$ ), the average grants are only $33-50 \%$ as large as those received by their older colleagues. Ishizaka says that Japan should break down some of its larger projects and spread out the money because the grants awarded to young researchers are often too small to support truly independent research.

\section{Civil war leaves Ivory Coast research in tatters}

\section{Marieke Degen, Munich}

The civil war raging in the Ivory Coast is counting scientific research among its many victims. Fighting and looting in what was one of Africa's wealthier nations have left international projects on health, agriculture and the environment in disarray.

When conflict between rebel and government troops erupted five months ago, foreign researchers working in disputed regions had to leave their scientific stations for their own safety. For some, the work that they left behind may never be recovered.

Last September, a team led by Eduard Linsenmair, an ecologist at the University of Würzburg, Germany, had to abandon its biodiversity studies in the Comoé National Park. The group has since heard that government troops have impounded the research station's cars and motorcycles.

"We learned that all of the buildings have been broken into and looted," Linsenmair says. Some of his projects will now be relocated to Benin, Burkina Faso and Ghana, but a lot of the data have been lost, he says.

Others have been a little more fortunate. In September, when rebels took over Bouaké, the Ivory Coast's second largest city, the $\mathbf{3 0}$ international researchers at the West Africa Rice Development Association (WARDA) were evacuated. They left behind one of Africa's most important rice gene banks. But some of the team returned on 17 December and recovered some 6,000 samples of recently developed rice varieties, says WARDA's director, Kanayo Nwanze. The association is now moving some of its operations to Mali.

Yasmin Möbius and Tobias Deschner from the Max Planck Institute for Evolutionary Anthropology in Leipzig also returned to their project in December. But they found that irreversible damage had been done.

Möbius and Deschner had been studying chimpanzee behaviour in the Taï National Park. Because the chimps are used to humans, they are easy prey for poachers. Soon after the researchers left the station in September, three female and three young chimps, including rare twins, were killed for food.

"We returned voluntarily," says Möbius. "It was important for us to ward off further attacks on the animals."

The situation in the national park stayed calm until 3 January, when fighting broke out near the Liberian border. The researchers returned to Abidjan, but left for Germany after fighting in the capital intensified.

A peace plan to end the war was discussed in Paris on 24 January, but has been rejected by supporters of President Laurent Gbagbo. "The war is a catastrophe," says Linsenmair. "All we can do is wait and hope it will end."

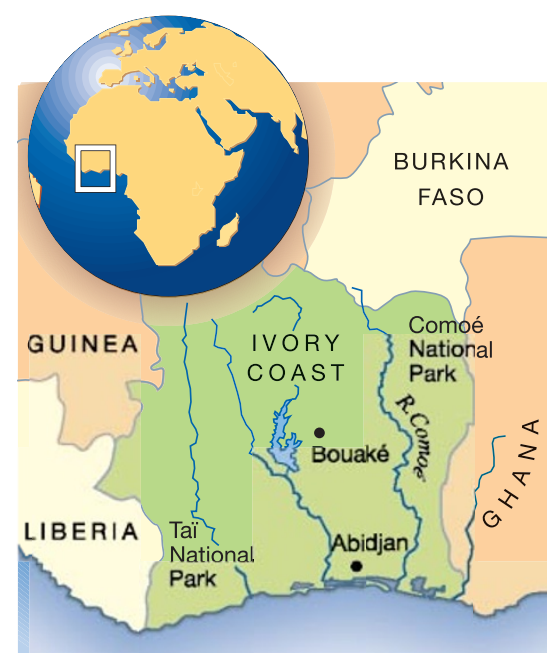

